\title{
CRIMINAL AND ADMINISTRATIVE CULPABILITY OF LEGAL PERSONS AND COMPLIANCE PROGRAMMES
}

\author{
Manuel Gómez Tomillo
}

\section{Abstract}

The paper deals with a concept of culpability for legal persons. To achieve this objective, special consideration is given to compliance programs adopted before the commission of the crime or administrative offense. Essentially it coincides with the idea developed by German dogmatics and conceives it as organisational fault. In that context, the role of compliance programs and their effectiveness in the determination of the specific sanction is examined. The idea is defended that they can operate by attenuating and, exceptionally, excluding responsibility. It goes beyond what has hitherto been the usual criterion, especially in the context of the law on competition.

Keywords

Legal persons. Culpability. Organisational fault. Compliance programs. Administrative sanctions.

\section{Summary}

1. Introduction. 2. State of the debate. 3. Culpability as an organizational failing. 4. Elements of the judgement of culpability in cases of administrative infringement (and crimes) attributable to legal persons. 5. Special consideration of compliance programmes adopted prior to the commission of the administrative infringements. 6 . The question of the burden of proof. 7. References

${ }^{1}$ Full Professor of Criminal Law, University of Valladolid - Spain. Lawyer of the Spanish Constitutional Court. 


\section{INTRODUCTION}

It is known that within legal orders, in which there is a clear distinction between Criminal Law and Administrative Sanctioning Law, the possibility of applying the latter to sanction legal persons ${ }^{2}$ frequently arises. In continental European countries, the administrative liability of legal persons often existed earlier in time to criminal liability, which has progressively been implanting itself within multiple positive systems (with the very notable exception of Germany). It has meant that the theory of the liability of legal persons has achieved notable scope, following an inverse path to what might be considered normal. Historically, the influence of Criminal Law over Administrative Sanctioning Law has been the norm, in view of the evidence of their common historic origin and their more than probable essential unity. In this particular field, on the contrary, Administrative Sanctioning Law has had the opportunity to go on ahead, straightening the path towards the potential admissibility of the criminal liability of legal persons $^{3}$. In fact, Germany, where crimes may not in a strict sense be

2 The existence of Administrative Sanctioning Law is not as universal as might usually be thought. It is still somewhat exceptional in numerous countries within our legal and cultural setting; leaving aside the Anglo-Saxon countries and, especially the United States of America, there are many European countries in which no true sanctioning authority of the Administration leaves an almost absolute predominance of Criminal Law, which is the case of Denmark and Sweden, to mention only a few examples. In general, vid. the study of CASERMEIRO 2010, 69 et seq. Contrary to the idea according to which there is strictly speaking no Administrative Sanctioning Law in the Anglo-American legal system, vid. BETANCOR 2009, passim.

${ }^{3}$ It appears to me that, in this context, the position of Hirsch should be underlined, with which I fully concur; this author underlines that if, on the one hand, culpability is required in the Contraventions Law and, on the other, in that context the capability of legal persons to admit to culpability is recognized, then as a logical consequence, their culpability may also be discussed in Criminal Law, in so far as there are no qualitative differences between one and another branch of Law HIRSCH 1993, 1110. With regard to the discussion on the 
attributable to legal persons, is the place where, very frequently following the strands of Administrative Sanctioning Law, both an important theory of the attribution of infringements to entities and their culpability were developed. This work seeks, precisely, to centre on the latter question ${ }^{4}$. It is perhaps not excessive in this context to highlight that I am referring to the third of the characteristics that accompany the action, or omission, in the most common definitions of the administrative infringement (or criminal offence $)^{5}$. It makes no sense to speak here of procedural culpability, linked to the presumption of innocence, and the idea of whether the infringement was or was not committed, or to improvise a diverse construct, alongside decades of progressive juridical-punitive thought processes. We begin, therefore, from a definition that, coinciding with the construct of the criminal offence, understands it as an action or an omission, written into law, that is both unlawful, and culpable ${ }^{6}$. In consequence, it becomes

legal nature that both sectors of the legal order present, vid. GÓMEZ TOMILLO et al. 2017.

4 Not without reason has the confused nature of culpability been underlined in Administrative Sanctioning Law NIETO, 2012, 572; or the numerous commentaries that it has raised PEMÁN GAVÍN 2000, 292. A warning of the need for precise calibration of the requirement of culpable responsibility CASINO RUBIO 2015.

${ }^{5}$ Upholding the need to require culpability also in the field of Administrative Sanctioning Law, vid.: KREMNITZER et al 2001, 551; they underline the coincidence with the penal concept of culpability, ROSENKÖTTER 2002, 79; GÖHLER 2017, 30; REBMANN et al 2016, 45. In Germany, however, they speak of reproachability in relation to administrative infringements, instead of culpability, as a consequence of the wording of $\int$ $1 \mathrm{OWiG}$, despite which the identity of both concepts is usually the conclusion; for example, vid. ROGALL 2014, 8.

6 The administrative scientific literature has taken it upon itself to underline that the definition expressed above is fully applicable in relation to administrative infringements: for Germany, vid. TREDER 1996, 9 et seq.; THIESEN 2002, 50-1. In Germany, it is a concept that is taken from $\int 1$ of the $O W i G$. The latter precept is defined as an "illegal and reproachable action defined in law and that can be sanctioned with a fine', from which all the elements of the definition expressed in the text, which is coincident with that of the criminal offence, may be inferred. The same opinion is maintained among criminal lawyers, 
necessary to define what is understood by culpability when applied to legal persons ${ }^{7}$.

\section{STATE OF THE DEBATE}

When approaching the problematic issue of the culpability of legal persons, both in Criminal Law and in Administrative Sanctioning Law, it may be maintained, in summary, that there are at least, three starting options ${ }^{8}$. One is to consider that it is not necessary to maintain the requirement of culpability when the offender is a legal person'. Another is to turn to culpability by

which is to say, the administrative infringement responds to the same concept as the criminal offence, MITSCH 2005, 2; ROSENKÖT'TER 2002, 14; BOHNERT 2000, 162 et seq.; RASCHAUER 2005, 46 et seq..; THIESS 2002, 122 et seq. The same point of view is even upheld beginning with mixed theses, with respect to the differentiation between criminal offences and administrative infringements; vid., REBMANN et al 2016; ROGALL 2014; and, it is equally upheld among the few supporters of a material distinction, LEMKE et al 2005, 22. They underline that in Italy the legal definition, the illegality of the act, and culpability must all concur, for example, PALIERO et al 1988, 217 et seq., requiring a review of all three categories; CERBO 1999, 67 et seq. In Spain, among others, vid. CANO CAMPOS 2001, 196; IZQUIERDO CARRASCO 2007, 34; GARCÍA GÓMEZ DE MERCADO 2002, 68; GONZÁLEZ NAVARRO 2007, 2890; AÑÍBARRO PÉREZ et al 2005, 61; GARCÍA GÓMEZ 2002, 67 et seq.; ZORNOZA PÉREZ 1992, 174 and SUAY RINCÓN 1989, 25-26, underlining, with reason, that it is not because no such definition exists in Law that it does not exist, because the Constitution obliges it to be sought on the basis of the need to uphold the application of the principle of legality to the administrative infringement. L. Parejo Alfonso provides a subsequent definition in the context of urban planning Law, but in which some gaps are detected: PAREJO ALFONSO 2006, 132.

7 In Spanish jurisprudence, vid. Constitutional Court Judgement STC 246/1991, of 19 December, Point of Law 2, (and, subsequently, in STC 129/2003, 30 June, Point of Law 8). On the aforementioned administrative judgement (in relation to STC 246/1991', RAP 129, 1992, pp. 211 et seq.; NIETO MARTÍN 1996, 205-9. On a critical note, vid. BAJO FERNÁNDEZ 1996, 28.

8 Among others, vid., ENGELHARDT 2010, 353 et seq.

${ }^{9}$ It is an idea maintained in Germany by Schünemann. This author understands that the only possibility of legitimizing the imposition of a criminal or an administrative sanction on legal persons, in the absence of culpability, lies in what is called the state of necessity of 
representation, in other words, the culpability of the physical person whose acts are real, is attributed to the legal person ${ }^{10}$. Finally, a form of specific culpability may be envisaged for firms and collective organizations.

In my opinion, I cannot share the negatory theory that there is no need to maintain the culpability requirement for offending legal persons. Once the liability of the legal person is accepted, due to the commission of administrative infringements (and criminal offences), both de lege lata, and de lege ferenda, there are solid reasons that support the requirement for culpability, and likewise when entities other than physical persons are accused of those infringements ${ }^{11}$.

In the first place, it should be considered that refusing the culpability requirement for legal persons might imply an unacceptable interpretation of the principle of proportionality ${ }^{12}$. In effect, if the culpability of legal persons is dismissed, the sanctions against them must be exclusively founded on preventive reasons, a question of dissuading the commission of certain behaviours. As no limit on culpability exists, the imposition of very high, even disproportionate sanctions may follow, in order to achieve the ends

the legal asset (SCHÜNEMANN, 1979, 235 et seq.). It is worth reasoning the imposition of a sanction, whether criminal or administrative, without invoking culpability, with the same arguments that are used for the application of the security measures. In any case, this author reached the conclusion that, provided it is possible to identify an individual author, the sanction on the organization should be dismissed, which is not valid in the system that we are analysing here. Moreover, there is a development in his thinking on which we cannot comment; on this point, vid., GÓMEZ-JARA DÍEZ 2005, 170 et seq.

10 Probably, and with nuances, this is the position of HIRSCH 1993, 1110 et seq.

${ }^{11}$ In a very close sense, vid., BRENDER 1989, 111 et seq. who highlights the acceptability of the Ordnungswidrigkeiten or administrative offences for their development, because of their younger nature, considering at the same time the growing power of firms, vid., likewise, NIETO MARTÍN 2008, 115 et seq.

12 Such a possibility means an awareness of whoever might sustain the need to forsake culpability, as they insist on submission to the principle of proportionality: SCHÜNEMANN 2000, 241. 
that are pursued, whether these are exaggerated or legitimate.

In second place, the thesis criticized here can raise problems from the point of view of the equality principle, in so far as it is precisely sustained that the judgement of culpability has among other functions that of individualizing offender liability, i.e. considering the individual factors of the infringement. In this way, the focus is at that moment on the inequality between each party, incorporating the thought into Sanctioning Law that not only is equalness to be treated as equalness, but inequality likewise as inequality ${ }^{13}$. Leaving aside the culpability of legal persons, both in Administrative Sanctioning Law and in Criminal Law, leads one to treat as an equal whoever has no reason to be censored, rather than whoever can be reproached for something, for example, an organizational failing.

In third place, having accepted the ontological identity between administrative infringements and criminal offences, constructs must be decided upon, in so far as possible, that permit the parallelism between both categories to be maintained. In other words, greater homogeneity between the punitive systems, establishing the highest level of possible guarantees, considering the consequences of Administrative Sanctioning Law that are highly likely to affect the lives and the patrimony of the persons. On the contrary, a risk-related sanctioning liability would be invoked, which has a reasoned basis within the area of Civil Law, but lacks any sense in a Law of a punitive nature.

Assuming the need for culpability attributable to legal persons at the core of administrative infringements, in accordance with that statement, some propose the so-called theory of representation, in other words, attributing to the legal person the culpability of the physical person. From our point of view, such a construct should likewise be rejected, for at least two reasons.

${ }^{13}$ For example, vid., TORÍO LÓPEZ 1985, 300; beginning from a different concept, the idea is also presently found, for example, in TOLEDO et al 1985, 298; MIR PUIG 2015. 
For one thing, with it, some of the advantages of attributing liability to legal persons are lost. In particular, the difficulties appear associated with having to individualize responsibilities within large complex business structures (the culpability of a natural person whose physical conditions are unknown can only be poorly transferred to a legal person). Another thing is that the theory of representation, in the last instance, implies a liability for the acts of another that is incompatible with the principle of personality applied to sanctions ${ }^{14}$. In short, it implies a confusion of responsibilities, of both the natural and the legal person; the existence of solid reasons is ignored for attributing liability to the latter that is answerable for its own unlawfulness and a differentiated culpability.

In view of the above, I favour, together with a broad current of opinion, the culpability of legal persons, founded on a single construct, adapted to these special organizational structures ${ }^{15}$. The problem is the conceptual delimitation of that culpability characteristic of legal persons, to which the following section is dedicated.

\section{CULPABILITY AS AN ORGANIZATIONAL FAILING.}

I understand that in the same way as happens when considering natural persons, the judgement of the culpability of legal persons should involve scrutiny of the individual factors, of the infringement, ignored in the

${ }^{14}$ In the same sense: among others, vid., GÓMEZ-JARA DÍEZ 2010, 141 et seq..; ZUGALDÍA ESPINAR 2001, 893; FEIJOO SÁNCHEZ 2002, 56 et seq., where subsequent bibliographic information is provided; BACIGALUPO SAGESE 1998, 176 et seq.

${ }^{15}$ For an analysis of the critical positions with the possibility of accepting the potential culpability of legal persons, vid., GÓMEZ-JARA DÍEZ 2010, 81 et seq. In the field of Criminal Administrative Sanctioning Law, in the strict sense, a specific culpability for legal persons is demanded, OSÓRIO 2015, 470. 
judgement of unlawfulness. Starting with such assumptions, from our perspective, the most acceptable construct in the actual state of the legal science is probably, with certain nuances, the one that TIEDEMANN developed (following the thread of administrative infringements), in accordance with which one should speak of the culpability of legal persons in terms of an organizational failing ${ }^{16}$. From that point of view, it would be the judgement of censure that is formulated against a legal person, because it has omitted the adoption of precautionary measures that are demandable of it, in order to guarantee an orderly and not an infractious development of the activity relating to the act of the firm ${ }^{17}$. Such culpability is particularly patent in the hypothesis in which the protagonism of the legal person in the act is not due to particular actions of a party embedded within it, but to the culmination of individual operations of natural persons locked within the

16 TIEDEMANN 1988, 1172; TIEDEMANN 1996; on the development that his disciple makes BRENDER 1989, 105 et seq. The Spanish administrative doctrine, can in some way be understood to accept the proposed model, in some cases. REBOLLO PUIG 1989, 769; covering the possibility without pronouncing upon it, vid., GALLARDO CASTILLO 2008, 210; vid., without expressly using such a concept; similarly, Lozano Cutanda has maintained that the legal person should be attributed liability, due to unacceptable employee vigilance LOZANO CUTANDA 2015, 227; specifically and quite accurately reflected in the concept of Tiedemann, PALMA DEL TESO 1996, 203, although as a criterion for the attributability of the infringement, with which, I understand, the planes of culpability and the unlawful act would be confused. For a critical stance towards the idea of Tiedemann, for example, in Germany, vid., ROGALL 2014; or among the criminal lawyers of that country, ROXIN 1997, for whom it is still fictional, because the organization at fault cannot be managed by the collective person, but by its directors. In Spain, BAJO FERNÁNDEZ 1996, 31 .

${ }^{17} \mathrm{It}$ is almost not worth insisting that the judgement of censure should be understood beyond any sort of ethical connotation, in as much as the behaviours attributed to the legal persons are completely without any class of moral motive. In consequence, this reproach equates with censure, disapproval of the behavior, which may be determined in accordance with social, cultural, or purely juridical parameters, but absolutely not ethical ones; in general, vid., CIGÜELA SOLA 2015, 247 et seq. Moreover, as is evident, it is an eminently valuative judgement of character; this aspect as BRENDER 1989, 112. 
universal structure of the collective organization in question ${ }^{18}$. It would be a complex judgement, in which it would be necessary to examine, in a similar manner to the judgement of the culpability of natural persons, a plurality of elements (as we will have the chance to address in the following point). We would, in the end, be before a judgement that would not automatically be present in the cases where the objective elements of the criminal act are verified. Instead, on the contrary, it might exclude sanctioning liability, when the legal person accredits proper organization, so as to avoid administrative, or criminal, unlawfulness (in that respect, it should be recalled that the burden of proof for the exclusion of culpability falls to whosoever alleges it, a question to which we will return below $)^{19}$.

We cannot enter into a detailed analysis of serious alternative constructs to the one expressed here ${ }^{20}$. Prominent among them in Spain is perhaps that

${ }_{18}$ Nevertheless, I share the idea of A. Nieto Martín, according to which the hierarchical level of the individual perpetrator is a reliable enough indicator of the degree of culpability. NIETO MARTÍN 2008, 162-3.

${ }^{19}$ I cannot, therefore, share the same criterion of Tiedemann, according to which the firm cannot free itself from the sanction through proof of an efficient organization; as neither do I understand the conception of his disciple M. Brender, according to which the firm can only expunge liability by proving the connective link is inexistent BRENDER 2019, 117. It is one of the points in the construct of Tiedemann that has stimulated most criticism; thus, in Spain, among others, B. Feijoo Sánchez, who underlines the fusion of culpability with other sorts of objective elements FEIJOO SÁNCHEZ 2002, 70 et seq.; in the same sense, I interpret ACHENBACH 1995, 405; vid., likewise, NIETO MARTÍN 1996, 208, who affirmed that 'we cannot pronounce the culpability of the legal person itself and then dismiss it or presume its existence... the correct path lies in admitting the absence of culpability of the legal person in those circumstances in which it is demonstrated that the firm has exercised all necessary diligence so that unlawful acts are not committed within it; on the question, vid., GÓMEZ-JARA DÍEZ 2010, 153 et seq. who in p.159 uses the same citation of the earlier author.

${ }^{20}$ For example, it turns out to be very close to the one that Engelhart proposed, who prefers to speak of a deficient business atmosphere ENGELHART 2010, 673. None other than Engelhart recognizes that it is a conceptual construct rooted in the construct of Tiedemann ENGELHART 2010, 675. He sustains that such a deficient business culture 
of GÓMEZ JARA. The culpability of the legal person for the aforementioned author equates to a business culture of non-compliance with legality ${ }^{21}$. However, I understand that a construct of this nature, however suggestive, is excessively ambiguous ${ }^{22}$ and determines an excessive restriction of the sanctioning possibilities, reduced to the field of the exceptional, given that such a culture is more one of criminal organizations than of legal persons that operate in the market and only exceptionally, commit a criminal offence, or, in so far as is of interest to us here, an administrative infringement ${ }^{23}$. Moreover, culpability requires a connection

exists when sufficient measures are not adopted within the firm to prevent the risks that materialize in the individual action of the staff of the organization ENGELHART 2010, 673.

21 GÓMEZ-JARA DÍEZ 2010, 9; GÓMEZ-JARA DÍEZ 2012, 117 among his other works. The idea of the business culture as the basis for the liability of legal persons appears in Anglo-American Law; Bucy specifically proposes it, who maintains that the possession of a different ethos adds meaning to the attribution of corporate liability BUCY 1991, 1095; the criterion is found in United States Sentencing Commission Guidelines Manual, \8B2.1, 'Effective Compliance and Ethics Program'; such an idea of corporate culture as the basis for liability crops up in the same draft of the Australian Penal Code (501.3.1; 501.3.2), cit. por HARDING 2007, 144; on the Australian Criminal Code, 12.3. vid., (1); GOBERT et al 2003, 74. It is of no less interest that in the same Anglo-Saxon doctrine it is stated that corporate ethos is the functional equivalent to attitude or willingness to behave characteristic of human beings (i.e., HARDING 2007, 145). In Spain, for example, vid., PÉREZ MACHO 2017, 76.

22 Highlighting the ambiguity of the construct, WELLS 2001, 138; it is likewise significant the criticism of the Australian doctrine, at the heart of which is the affirmation that 'Such an amorphous concept as 'corporate culture' provides considerable scope for the raising of a reasonable doubt...' CLOUGH 2007, 283). In the same way, it cannot be overlooked that in Canada the concept is precisely rejected with the argument of its vagueness: Government of Canada, Corporate Criminal Liability. Discussion Paper, 2002, 11. Even among the defenders of the model, it is accepted that it provides a certain dose of uncertainty: CAVANAGH 2011, 440. For a broad presentation and criticism, vid., CIGÜELA SOLA 2015, 207 et seq.

${ }^{23}$ In the work of CUESTA ARZAMENDI 2011, the author shares that point of view who therefore adheres to the idea of Feijoo Sánchez who in turn speaks of a lack of culture of 
with the unlawful act that is committed and the idea of entrepreneurial culture can find itself excessively delinked from the concrete act that determines the liability, given that it is a concept that implies a broad prolongation over time. In other words, a recently created firm can clearly be accused of a criminal offence or an administrative infringement, but only with difficulty can one say that it lacks a culture of compliance, given that such a culture, it appears, cannot be improvised overnight (although an organizational failing can be, an idea that has a more eventual character). Finally, an injustice consisting of the absence of a certain culture might clearly imply a transition from a Law that punishes the act to a sort of nonassumable Law sanctioning the perpetrator, associated, in our case, with the way the firm conducts its social, business and organizational life (Judgements of the Constitutional Court SSTC 150/1991 4 July, Point of Law 4;185/2014 of 6 November, FJ 3).

\section{ELEMENTS OF THE JUDGEMENT OF CULPABILITY IN CASES OF ADMINISTRATIVE INFRINGEMENTS (AND CRIMINAL OFFENCES) ATTRIBUTABLE TO LEGAL PERSONS.}

The problems have evidently not been solved with the adoption of a particular model of culpability. It is necessary to specify which elements integrate it or have to be examined in it.

It is known that culpability in the conventional formulas targeting natural persons is configured as a complex judgement integrated by a plurality of

compliance with legality CUESTA ARZAMENDI 2011,107 et seq.; likewise, on the criticism of this last author of the construct of GÓMEZ JARA 2014, 165 et seq., reflecting positive aspects in GÓMEZ JARA 2014,168 et seq. that can be shared; likewise, for criticism of the construct of PALMA HERRERA 2014, 183 et seq., underlining the absence of a legal basis for such a criterion on p. 184. If the culpability of legal persons is conceived not only as a 'culture of non-compliance' but as a 'lack of a culture of compliance', as Gómez Jara noted, on some occasions, we may understand that it improves the construct, against which the problems that are presented in the text still remain. 
elements: the awareness of unlawfulness, attributability, absence of a reasonable excuse, etc. ${ }^{24}$. However, the characteristic of the practical totality of the aforementioned elements is that they are designed with the natural person, rather than the collective body in mind. Thus, it has been sustained that within the category of the characteristic culpability of legal persons, it is necessary to eliminate those elements thought out for an individual with physical characteristics. Accepting such a starting point, however, one must be aware of the concrete circumstances of the case, so that the lack of culpability of the physical person that acts in the name of the legal person can, on occasions, exclude the liability of the latter or, on the contrary, be a symptom of an organizational failing. The elements that we are judging and that must be included in the judgement of the culpability of a legal person, especially if defined as an organizational failing of that party, will be the following.

In the first place, it is here where it must be set out whether or not there has been acceptable oversight, supervision and control over the staff with no managerial authority. It is, clearly, an appreciation of an assessable nature, only likely to be affirmed or negated once knowledgeable of the specific case and its circumstances.

In second place, culpability will be particularly patent, although not only, according to the hypothesis that the act in which the legal person has the leading role is not due to the particular actions of a person framed within it, but to an accumulation of improper individual operations of naturalpersons incorporated within the structure of the collective entity under consideration.

In third place, the matter of whether it is sufficient to exclude social culpability should probably be proposed, in this context, with the existence of express instructions from those with managerial authority over the worker so that the

${ }^{24}$ In Spain, in the field of administrative doctrine, for example, vid., HUERGO LORA 2007, 394, proposing a conditioned referral to the Criminal Code. 
worker abstains from carrying out the conduct (or, on the contrary, carries out a certain action that could, for example, exclude the harmful result), which will eventually provoke the corresponding criminal procedure. No general position may be taken on the question, but it depends on the set of circumstances in which the events take place, which imply assessing a broad set of elements, such as the emphasis with which instructions are issued, their clarity, the possibilities of adopting alternative safeguards, the capability of the individual receiving the orders, individual antecedents, etc. It explains the disparity of case-law decisions within the annals of comparative Law $^{25}$.

In fourth place, I understand that, systematically, it is here, in culpability, where some of the features of the natural persons really acting, or by their omission, as well as the presence or absence of excusatory causes, non-attributability, and probibitional error must be considered. However, the awareness of any of the above-mentioned elements will not automatically determine the exclusion of the liability of the organization, given that it can precisely constitute a

25 Some citations from English case-law may be very significant, because in that case-law there is no well-defined differentiation between Administrative Sanctioning Law and Criminal Law. Testifying as much, for example, the case of The Director General of Fair Trading $v$ Pioneer Concrete (UK) Ltd, also known as Ready Mixed concrete (n²), 1995: the employees of four firms agreed to fix the prices of their products against the express interdiction issued by their companies, without those workers having informed their managers, specifically the Board of Directors, of the practice that was taking place. The directors and executives (the directing mind and will of the company) were not aware of the events taking place. The firms were convicted, in spite of those express instructions, in so far as it was the firm that benefitted from such practices (this last-mentioned criterion would for me be insufficient for the conviction); vid., PINTO et al 2008, 329. Contradictory conclusions have been reached in the North-American jurisprudence; the case United States $v$. Hilton Hotels has frequently been cited, in which the firm was sanctioned despite the acknowledgement that the employee had flouted the express instructions of the company and ignored its policy (for a critical stance, vid., LAUFER 2006, 71; BRICKEY 1992; nevertheless, the cases in which liability has been excluded (id., \ 3:08); in a similar sense, vid., BUCY 1991, 1441 quoting cases extracted from the jurisprudence of that country. 
symptom of a failing organization. Thus, if a physical person without sufficient juridical knowledge adopts decisions that affect the legal person, under an error of prohibition, we are frequently facing nothing other than a symptom of that organizational failing, in so far as a sufficiently qualified person could have been contracted ${ }^{26}$. However, the possibility of accepting that an objective complexity of the regulation applicable to the case exists, for which reason it may be understood that there is either a vincible or an invincible error of prohibition that affects the legal person.

On the contrary, if whoever is acting, or ceases to do so in the case of omissions, does so under a transitory mental disorder, state of necessity, or driven by insurmountable fear, it may be concluded that the infringement that is committed is not a consequence of an organizational failing. Evidently, an evaluatory process is inevitable on the part of whoever is judging, as happens with the characteristic culpability of natural persons or within Criminal Law in the strict sense. Another thing is that, for example, the error of prohibition or non-attributability of an offence to those acting on behalf of the firm or the legal person can serve to adjust the punitive response against the collective entity. What is expressed is coherent with the point of view in accordance with which the legal person constitutes a plurality of substantial realities, differing from the members that integrate it, in such a way that their liability is adjusted upon the basis of categories that are not a mere transcription of the characteristics of the natural persons.

${ }^{26}$ In the criminal doctrine, the way that on occasions the organizational competency of the collective units is recognized, even when the natural persons that act on their behalf are not competent: vid., JAKOBS 1995. On the contrary, it has on occasions been sustained that the strict application of the principle of liability by representation, according to which the liability for the acts committed by the natural person are transferred to the legal person for which that natural person is acting, determines that the exclusion of the attributability of the offence to the former extends to the latter, for example, vid., KREMNITZER et al $2001,541$. 
In fifth place, and in coherence with what has been said so far, the intentional or imprudent nature of the natural person that is the real actor must be considered in the judgement of the culpability of legal persons. As I have already had the opportunity of making clear, the construct of the criminal offence, or of the administrative, intentional, or imprudent administrative infringement, committed by natural persons cannot be extrapolated to those commissioned by legal persons, given that those categories are clearly constructed for natural persons. For that very reason, I understand that the criminal intent and the imprudence of the natural person who is involved are not, in this case, elements of the unlawful act, but rather data that should be considered in the culpability, understood as an organizational failing. Evidently, such organizational failings will be greater, more censurable, when the behavior of the natural person who is acting is intentional rather than merely imprudent ${ }^{27}$.

In sixth place, I may, at least, add the hierarchical level of the individual offender, which, in the pertinent words of NIETO MARTÍN is quite a reliable indicator of the degree of culpability of the firm ${ }^{28}$.

Finally, the presence or absence of serious compliance programme will be central. Put another way, an organizational failing within a firm could not easily be censured, if it had introduced a suitable programme to prevent the commission of unlawful acts within it (another thing would be that it had a programme that may not be a serious programme, ex ante effective or even if it were, it may not be correctly implemented) ${ }^{29}$. It makes no preventive

${ }^{27}$ In Spain, I understand that A. Nieto Martín expresses a similar view, who understands that we are facing more or less serious circumstances of organizational failings NIETO MARTÍN 2008, 162. In Germany, the possibility has even been upheld that, despite the criminal intent of the natural person, it is the culpability of the legal person that is sanctioned, DANNECKER 1989, 289.

${ }^{28}$ NIETO MARTÍN 2008, 162.

${ }^{29}$ As indicated, Gómez Jara has been maintaining a position, according to which the origin of the culpability of legal persons is rooted in the generation of business culture of non- 
sense at all, if a party has exhausted all resources within its reach to prevent the commission of such acts, despite which it is sanctioned. It would be an unacceptable, unconstitutional circumstance of objective liability ${ }^{30}$, in which there can hardly be a need for sanctioning ${ }^{31}$.

\section{SPECIAL CONSIDERATION OF COMPLIANCE PROGRAMS ADOPTED PRIOR TO THE COMMISSION OF THE ADMINISTRATIVE INFRINGEMENT.}

compliance (GÓMEZ JARA, 2012, 117, among other works of this author); precisely for that reason, he maintains that the programmes of compliance are an indication of a certain business culture, for which reason they can be constituted on the basis of the exclusion of responsibility, due to an absence of culpability (GÓMEZ JARA, 2012, 115). On this construct, vid., B. Feijoo, FEIJOO, 2012, 81. Nevertheless, none other than Gómez Jara argued that the objective suitability of the compliance programmes is in response to the criminal offence (FEIJOO, 2012, 175). From our point of view, it enters into contradiction with the foundation of the recognition of the criminal liability of legal persons, which, as the same author robustly sustains, is rooted in the need to counter the growing power of those organizations, transferring the responsibility of implementing mechanisms for normative compliance, in view of the difficulties that the public prosecutor, judicial power, and members of the law enforcement bodies have when investigating what is happening within firms. If the suitability of the programme is a problem of the criminal offence, the burden of proof of that suitability is shifted to the prosecutor, which is incompatible with the end purpose that is sought with the requirement for such responsibility. Accepting the construct of Gómez Jara, it is understood that a suitable compliance programme excludes the culpability of the legal person PÉREZ MACHÍO 2018, 194.

30 With good reason, it has been affirmed that due diligence is the contrary to culpability (or fault), vid., J. GOBERT et al 2003, 100. I understand that this is the majority position in the Spanish doctrine; among others, for example, vid., LASCURAÍN SÁNCHEZ 2013, 212.

31 It is no less significant that culpability in criminal Law has been identified by some authors with the need to impose a punishment when the reestablishment of the legal force of the norm so demands, that is, founded on general positivist prevention BACIGALUPO SAGESSE 1998, 169 et seq. 
As has been pointed out, it appears clear that it is in the field of material culpability where it must be analysed whether the adoption of a compliance programme must have some sort of exonerating or extenuating sort of operational effect ${ }^{32}$. I refer here to the cases where that compliance programme may have been adopted before the commission of the administrative infringement (or criminal offence) and where, in addition, that programme is ex ante suitable for the prevention of its commission. We are not concerned now with cases of adoption posteriori, in so far as they refer to an act after the commission of the infringement, affecting neither the infringement, nor the culpability of the individual. In this last group of cases, I understand that the extenuating efficacy of compliance programmes will depend on whether Positive Law has established such a possibility, either specifically in relation to the administrative infringements, or in the Criminal Law of legal persons through what, I understand, would be an analogical application.

From our perspective, there are at least four arguments with which to propose that the compliance programmes adopted before the commission of the infringement should be generally operative, in order to calculate the applicable sanction in the field of Administrative Sanctioning Law, as an extenuating circumstance or, even, and in a very exceptional manner, for determining the exclusion of liability.

On the one hand, from a material perspective, having accepted that culpability forms part of the concept of the administrative infringement (or criminal offence) and having conceptualized it as an organizational failing, it appears clear that the aforesaid failing will not cease to exist in cases where an $e x$ ante compliance programme has been implemented, before the commission of the administrative infringement, that is suitable to prevent the commission of administrative infringements within a legal person. The

32 In general, a good doctrinal overview can be seen in AGUILERA GORDILLO 2018, 195 et seq. 
existence of a conceptual incompatibility between organizational failing and the existence of a suitable compliance programme hardly appears questionable. I repeat that if the organization had taken every possible step to avoid the commission of administrative infringements (or crimes), in spite of which the infringements took place, then the imposition of a fine makes no preventive sense at all, except if it within the context of a constitutionally censurable objective liability ${ }^{33}$. Whoever reworks the proposal that is expressed above, ought probably to develop a proper concept of culpability, rather than simply leave it as an open question ${ }^{34}$,

33 That is the censure that upholds the position of the European Commission, the Constitutional Court and the Court of Justice of the European Union, which, in principle, do not accept the adoption of compliance programmes with exonerating or extenuating effects on liability. Nevertheless, it must be taken into account that European case-law is expressing itself rather tepidly, interpreting in almost all cases that it is more a problem of accreditation of the suitability of the programme than a definitive dismissal of its operational effect either exonerating or excluding liability. In general, on the question, vid., PÉREZ FERNÁNDEZ 2014, 303 et seq., who highlight that a change of opinion has come about, citing various decisions in which other criteria were maintained (PÉREZ FERNÁNDEZ 2014, 304).

${ }^{34}$ Nevertheless, it must be underlined that the organizational failing can frequently be considered as an element of what is unjust and, despite that, the same conclusions are reached as expressed in the text, vid. CUESTA ARZAMENDI 2011; BLANCO CORDERO 2012, 855-881. We may highlight that Bajo Fernández sustained that the unjust act of a legal person requires, among other things, 'the absence of programmes of good governance... which discipline their directives and employees in compliance with the Law or that originate decisive organizational failings of the behavior defined as illegal' BAJO FERNÁNDEZ 2012, 34. Such a proposal appears to point to the legal definition itself which is where the presence of the absence of such programmes should be considered (they also sustained that the legal definition excludes the proper implementation of a programme of this nature MATA BARRANCO et al 2011, 4. In general, I cannot share the idea that the failing of the organization is a question of injustice, in so far as such an organizational failing might exist and, notwithstanding which, might pose no danger to the legal assets (for example, no measures for controlling the workers are enforced who, nevertheless, perform their duties properly). On the other hand, the absence of an organization failing with damage to legal assets would exclude the unlawfulness, for which 
especially if, as the Spanish Supreme Court has declared, culpability constitutes a structural requirement of the State living under the rule of Law (see, especially, SSTC 246/1991, of 19 December, Point of Law 2; 59/2008, of 14 May, Point of Law 11 b); 185/2014 of 6 November, Fto. Jco. $3^{\circ}$ in fine). It likewise appears reasonable that if the programme were not fully suitable, but it was assessably significant, then the sanction might be reduced.

On the other hand, the generalized introduction of these sorts of instruments unquestionably constitute a desirable objective. However, only if firms are granted some class of real operating capacity will firms be incentivized to implement them ${ }^{35}$. It is clear that simple reputational prestige is insufficient to stimulate their generalization, much less so if it is taken into account that their costs can be high, and, likewise, any potential access to clemency programmes, in the case of early detection. Among other reasons, because, if there is no early detection, normally the possibility of receiving less punitive treatment will be lost $\mathrm{t}^{36}$.

In third place, it is unreasonable that, in some fields of Administrative Sanctioning Law, the adoption of such programmes is granted extenuating

reason, even the path to potential civil liability would be closed. Broadly, on these questions, vid. GÓMEZ TOMILLO 2016.

35 It has even been affirmed that if either exonerating or extenuating efficacy is not accorded to the programme, it is a disincentive to carry it out. And that in so far as that it should normally be concluded that if the unlawful act was committed despite the introduction of the programme, then behavior was not negligent, but intentional, and, in consequence, more serious, which should raise the level of the sanction to be imposed (P. Pérez Fernández, 'La importancia de los programas de cumplimiento (compliance programmes) en las políticas sancionadoras...', op. cit., pp. 312-313). The question accepts, nevertheless, many nuances, which we shall not enter into here.

36 We support the opinion of P. Pérez Fernández, who highlights how contradictory it is to grant clemency programmes an extenuating or even an exonerating effect on liability in Competition Law and not to attach the slightest extenuating effect to the prior adoption of a suitable compliance programme PÉREZ FERNÁNDEZ, 2014, 312. 
and exonerating relevance in relation to liability and in others it is not. The internal coherence of a system that operates in such a way may be seriously questioned $^{37}$. The alternative might be to establish its obligatory nature and to sanction the non-compliance of that legal obligation, trusting more in the efficacy of a repressive Law than in the efficacy of a premium $\mathrm{Law}^{38}$. However, it may be thought that the most effective approach would probably be to establish that obligatory nature only in particularly sensitive sectors and to attribute general extenuative or exonerative efficacy to its

${ }^{37}$ For examples of comparative law, especially the competition, in which the compliance programmes are granted efficacy in PÉREZ FERNÁNDEZ 2014, 318 et seq.

${ }^{38}$ The first is the road that Germany has followed, through paragraph 130 OWiG. Likewise, Spanish Administrative Sanctioning Law employed a similar expression in the now repealed article 130.3 Ley 30/1992, as well as in some sectors of the special legislation. The cited paragraph, $130 \mathrm{OWiG}$, provides that '(1) Whoever as an owner of a business or a firm, in an intentional or imprudent manner, omits to take supervisory measures to avoid infringements in the business or the firm against duties incumbent upon the owner, infringements of which are sanctioned either criminally or administratively, will be administratively sanctioned when that infringement has been committed and it could have been avoided or hindered essentially through proper supervision. Among the necessary supervisory measures are found appointment, selection, and proper supervision. (2) Public firms will also be considered as firms or businesses, in accordance with the first section. (3) The administrative sanction can be up to one million Euros when the violation of the obligation is criminally sanctioned. When the infringement is sanctioned through an administrative fine, the fine can be equal to the fine that is imposed, due to the infringement of the obligation. The latter is also applicable in cases where the infringement is sanctioned at the same time both criminally and administratively, if the administrative fine is envisaged to exceed one million Euros'. In Spain, in matters of health and safety at work, vid., article 12.1 of Royal Legislative Decree 5/2000, of 4 August, in amendment of the text of the Law on Infringements and Sanctions in the Social Order. As far as the laundering of capital is concerned, it requires a combination of provisions established in Law 10/2010, of 28 April, on the prevention of money laundering and the financing of terrorism. Specifically, articles $26.1,52 \mathrm{~m}$ ) and 54 of the aforementioned Law should be considered, which present their individual problems, the details of which we will not enter into. 
$\operatorname{adoption}^{39}$.

Finally, the compliance programmes are not indifferent from the perspective of Administrative Sanctioning Law, in so far as this last branch of the legal order can no longer remain on the margin of what is both normatively and dogmatically occurring within the field of Criminal Law. The reason is found in the unity of the punitive Law of the State, which has to respond to both principle safeguards (although not to identical rules, because not even within Criminal Law in the strict sense are the rules homogeneous). Nevertheless, in any case, whether or not the unity between sectors of the legal order is accepted, I understand that it makes little sense, if some class of operating capacity is conceded to a compliance programme within Criminal Law, that is should simply be ignored in Administrative Sanctioning Law, as we are considering a branch of the legal order that is oriented towards the imposition of sanctions that can be of much greater seriousness than foreseen in the Penal Code ${ }^{40}$.

Beginning with the earlier points of view, the conclusion is plain to see: there should be no diverse solutions within both Criminal Law and Administrative Law on this matter. As things stand today, the possibility of proceeding with a reduction or an elimination of the sanction in Administrative Sanctioning Law is not usually contemplated with a general nature (except for certain very specific sectors), in the case where the legal person has adopted effective measures oriented towards the prevention of administrative infringements. However, in so far as Administrative Law offers no express solution to the question, it is always worth turning to Criminal Law through analogical reasoning, always to the benefit of the

${ }^{39}$ We refer, on that matter, to our work GOMEZ TOMILLO 2016, passim.

40 The development of the question in North-American Law is, in that respect, particularly interesting, where the existence of compliance programmes not only influences the punishments in the strict sense of the firms, but also the scope of the so-called civil sanctions there; in that respect, vid., ENGELHARDT 2010, 286. 
offending party, in this case the legal person. In short, once again, the state of the question in Criminal Law, as it has been expressed here, is in no way indifferent. If it is accepted that compliance programmes can be of exonerative efficacy for criminal liability, it is hard to see why it should not operate in the same way in Administrative Sanctioning Law ${ }^{41}$.

Beginning with the earlier assumptions, it must be taken into account that in the circumstances of unlawful acts carried out by legal or executive representatives, in the name of or on behalf of the firm, it will be particularly difficult for a compliance programme to have in practice extenuating or exonerating operating capacity ${ }^{42}$. Expressed in other words, from a purely statistical point of view, it appears reasonable to understand that the legal operating capability of those programmes will enter into play, above all, in the case of behaviours committed by employees with no managerial power and, especially, although not only, in the case of imprudent behavior, rather than behavior involving criminal intent ${ }^{43}$.

Regardless of whether the concrete infringement has been committed by a person in an executive or a subordinate position in the business and social structure, it appears clear that the suitability of the programme at avoiding criminal offences and administrative infringements within the legal person must be contemplated from an ex ante perspective, even though expost such

${ }^{41}$ In the words of Nieto Martín, 'the criminal liability of legal persons has as its end to motivate firms to increase their level of self-regulation and to establish the necessary mechanisms for management, organization and control, to avoid the commission of criminal acts... In this sense, compliance programs or organizational models are key', NIETO MARTÍN 2008, 215. Evidently, the criteria are extrapolatable to the field that concerns us here, in which there is no doubt that the compliance programmes should have exonerative efficacy, provided that, ex ante, they present effective methods for the control of behavior. 42 In the following sense, LAUFER 2006, 129.

${ }^{43}$ In the case of executives, they probably differ with good reason as a function of whether it is a matter of various administrators or only one LASCURAÍN 2013, 120-1.

Human(ities) and Rights | GLOBAL NETWORK JOURNAL | Vol.2 (2020) Issue 1 | 28 
a programme had not proved sufficient ${ }^{44}$. What cannot rationally fit is the demand for a perfect compliance, without cracks, that, in all probability, would be incompatible with a reasonably effective exercise of the entrepreneurial $\operatorname{tasks}^{45}$.

In the same way, and as is obvious, a merely cosmetic compliance programme should not determine exclusion, nor even a lesser liability of the firm.

In practice it will be particularly complex, in concrete cases, to accredit that the programme was objectively suitable, to prevent the commission of criminal offences or administrative infringements ${ }^{46}$ and, in consequence, to give it exonerative efficacy upon liability (unlike the extenuative). As will be expressed in what follows, we understand that the legal person is charged with providing the proof of a non-failing organization, which leads one to think that full exemption of liability would be an exceptional, although not an impossible situation. It should be taken into account that, on most occasions, the verification of the criminal offence or of the administrative infringement will be a symptom of an improperly designed programme. The only thing worth understanding as exceptional is that the programme is properly designed and implemented and, despite which, the criminal

${ }^{44}$ I interpret GÓMEZ MARTÍN 2011, 134, in a similar sense when he requires that the programme be objectively suitable to prevent the commission of crimes. In this context, vid., exhaustively, the monumental work of ENGELHART 2010.

${ }^{45}$ On the connection of the compliance programme and permitted risk, vid. Palma Herrera 2014, 207-8.

46 E. Bacigalupo underlines the difficulties so that the extenuating circumstance may be appreciated in article 31 bis $4 \mathrm{~d}$ ) Spanish Penal Code, which is that of having established effective measures prior to the oral judgement to prevent and to discover the criminal offences that in the future could be committed with the resources or under the cover of the legal person. He indicates, quite rightly, that it would be difficult to appreciate with an expert report, given that the judgement that it requires is not only of a legal nature. As Bacigalupo himself affirms, 'the object of the test is the same as that required for accrediting the irreproachability of the organization' BACIGALUPO ZAPATER 2011, 95. 
offence or the infringement is committed. The experience of comparative Law appears to corroborate the above ${ }^{47}$. Evidently, it is a question of encouraging the introduction of effective compliance programmes, not of creating mechanisms for impunity for legal persons, in cases where criminal or unlawful administrative behaviours take place within them ${ }^{48}$.

If the earlier points of view are accepted, the problem arises of the extent to which the administrative sanction may be reduced in favour of the legal person that has adopted an effective compliance programme. Such a problem is present in so much as administrative Law, will not normally contemplate the adoption of such programmes as extenuating circumstances, and much less so as exonerating ones. From my perspective, at least, the sanction should not exceed the minimum threshold established in the Law. Nevertheless, both for reasons of proportionality, and by an analogical application of the rules of Criminal Law, wherever considered, they should in such cases propose lowering that threshold.

\section{THE QUESTION OF THE BURDEN OF PROOF ${ }^{49}$.}

47 Although it is not a question of fully updated data, vid. LAUFER 2006, 119, where he highlighted that in the period between 1996 and 2004, only two of the convicted companies had a really effective compliance programme. The same author highlighted that extenuation due to the existence of the programme is very rarely offered to the companies that are convicted. Nevertheless, such a situation is explained by very different factors that Laufer also highlighted. The existence of those programmes usually allows the facts to be linked to the civil environment, facilitates an agreement between the parties and turns the investigation towards the natural persons who really intervened in the acts (ibid.), which is coherent with the discretion that the prosecutor can exercise. In Spain, vid. MUÑOZ DE MORALES ROMERO 2013, 214.

48 Which amounts to a global idea; vid., in the same sense LAUFER 2006, 189.

49 Once more: We do not share the same criterion of Tiedemann, according to which the firm cannot free itself from the sanction through proof of an efficient organization: see supra note 18 . 
What has been expressed-leads us to the question of the burden of proof ex ante of the programme, to prevent the commission of unlawful acts within the heart of the enterprise. It will be examined from the particular perspective of the compliance programmes, although what has been affirmed is valid for any other of the integral elements of the culpability of legal persons that have been described. From this perspective, as with all the questions pertaining to culpability, the burden of proof of the concurrency of circumstances that might exclude it will fall on the perpetrator, the legal person; the reasons for which are multiple.

In the first place, it is reasonable to exonerate from the proof that which is exceptional: what is normal may be presumed. As already said, on most occasions, the verification of the infringement (or, if applicable, of the criminal offence) will be a symptom of an improperly designed compliance programme. Exceptional may only be understood in terms of a properly designed and implemented programme, despite which, the unlawful acts are committed. The experience of comparative Law appears to corroborate the above $^{50}$, i.e. that the full exoneration of liability will be an exceptional, although not an impossible situation (unlike its mere extenuation).

In second place, because it is not in practice feasible for the prosecution (or the Administration in the case of Administrative Sanctioning Law) to assume the burden of proof of a negative element: the absence of a failing organization. The contrary would suppose burdening such a prosecution with an impossible probatio diabolica ${ }^{51}$.

50 Although it is not a matter of fully updated data, vid. LAUFER 2006, 119, where it is clearly stated that, over the period between 1996 and 2004, only two of the convicted companies had a really effective compliance programme.

51 Gómez Martín has defended that the probatio diabolica would be present, if the defence were demanded to accredit that the organization had no failing GÓMEZ MARTÍN 2012, 252. I understand that the question depends on how the problem is formulated. If the 
In third place, there are evident practical reasons, given that it is the firm that holds the precise information for its accreditation: the compliance programme, the information on whoever was named the compliance officer, the existence of updates of that programme, whoever was in charge of carrying out a specific task, which were the reasons for appointing that employee, following which criteria, etc. It is artificial to transfer the burden of proof to the prosecution for proving what is easily found at the disposal of the legal person.

Finally, what has been defended here is in line with what is highly frequent in Anglo-Saxon law concerning the legal defence of due diligence without questioning therein the violation of fundamental guarantees ${ }^{52}$.

\section{REFERENCES}

AGUILERA GORDILLO, R. Compliance penal en España, Pamplona, 2018. AÑÍBARRO PÉREZ, S.; SESMA SÁNCHEZ, B. Infracciones y sanciones tributarias, Valladolid, 2005.

defence is required to accredit that there was a diligent and not a failing organization, for example, through the presentation of the corresponding compliance programme, its suitability certified by external firms, or public entities, etc. then the problem will lessen. However, it is not reasonable that the prosecution, the function of which is precisely to prosecute, accredit that diligent or non-failing organization, which is the sole positive point that may be proven.

52 One only needs to consult GOBERT et al 2003, 100-2; Law Commission Working Paper, Consultation Paper 195, Criminal liability in regulatory contexts, 1.68; 1.69, 6.1, 6.19 etc. WELLS 2001, 102, with quotes from the case that is referenced, Tesco $v$. Nattrass, with evident proximity to the Administrative Sanctioning Law of countries within the influence of European continental Law. 
BACIGALUPO SAGESE, S. Responsabilidad penal de las personas jurídicas, Mardid, 1998.

BACIGALUPO ZAPATER, E. Compliance y Derecho penal, Madrid, 2011.

BAJO FERNÁNDEZ, M. "La responsabilidad de las personas jurídicas en el Derecho administrativo español", Responsabilidad penal de las empresas y de sus órganos y responsabilidad por el producto, MIR PUIG, S. et al coords., Barcelona, 1996.

BAJO FERNANDEZ, M. et al. Tratado de responsabilidad penal de las personas jurídicas, Madrid, 2012.

BETANCOR, A. "Derecho administrativo sancionador en el sistema jurídico británico: Regulatory enforcement and sanctions Act" Revista General de Derecho Administrativo, n¹9, 2009.

BLANCO CORDERO, I. El delito de blanqueo de capitales, Madrid, 2012

BOHNERT, J. "Einleitung", Karlsruber Kommentar zum Gesetz über Ordnungswidrigkeiten, BOUJONG, K. ed., München. 2000

BRENDER, M. Die Neueregelung der Verbandstäterschaft im Ordnungswidrigkeitenrecht, Freiburg, 1989.

BRICKEY, K. Corporate criminal liability, Kentucky, 1992

BUCY, P. "Corporate ethos: a standard for imposing corporate criminal liability", Minnesota Law Review, n75, 1991.

CANO CAMPOS, T. "Non bis in idem, prevalencia de la vía penal y teoría de los concursus”, Revista de Administración Pública, n 156, 2001.

CASINO RUBIO, M. "La potestad sancionadora de la Administración y vuelta a la casilla de salida." Documentación Administrativa, n², 2015.

CAVANAGH, N. "Corporate criminal liability: an assessment of the models of fault”, Journal of Criminal Law, 2011. 
CERBO, P. Le sanzioni amministrative, Milano, 1999.

CIGÜELA SOLA, J. La culpabilidad colectiva en Derecho penal, Madrid, 2015.

CLOUGH, J. "Bridging the theoretical gap: the search for a realist model of corporate criminal liability", Criminal Law Forum, 2007,

CUESTA ARZAMENDI, J.L. de la. "Responsabilidad penal de las personas jurídicas en el Derecho español", Revista Electrónica de la AIDP, 2011.

ENGELHARDT, M. Sanktionierung von Unternehmen und compliance. Eine rechtssvergleichende Analyse des Straf- und Ordnungswidrigkeitenrechts in Deutschland und den US A, Berlin, 2010.

FEIJOO SÁNCHEZ, B. Sanciones para empresas por delitos contra el medio ambiente, Madrid, 2002.

GALLARDO CASTILLO, M.J. Los principios de la potestad sancionadora, Madrid, 2008.

GARCÍA GÓMEZ DE MERCADO, F. Sanciones administrativas. Garantias, derechos y recursos del presunto responsable, Granada, 2002.

GARCÍA GÓMEZ, J. La simple negligencia en la comisión de infracciones tributarias, Barcelona, 2002.

GÖHLER, E. Ordnungswidrigkeitengesetv, Munich, 2017.

GOLBERT, J.; PUNCH, M. Rethinking corporate crime, Cambridge, 2003,

GÓMEZ MARTÍN, V. "Falsa alarma. O sobre por qué la Ley Orgánica 5/2010 no deroga el principio societas delinquere non potest", Garantías constitucionales y Derecho penal europeo, MIR PUIG, S. et al ed., Madrid, 2012.

GÓMEZ MARTín, V. Comentarios al Código Penal, Reforma LO 5/2010, Valencia, 2011. 
GOMEZ TOMILLO, M. Compliance penal y politica legislativa, Madrid, 2016.

GÓMEZ TOMILLO, M. Introducción a la responsabilidad penal de las personas jurídicas, Madrid, 2016.

GÓMEZ TOMILLO, M.; SANZ RUBIALES, I., Derecho administrativo sancionador Parte general, Madrid, 2017.

GÓMEZ-JARA, C. "Fundamentos de la responsabilidad penal de las personas jurídicas", Tratado de responsabilidad penal de las personas jurídicas, Madrid, 2012.

GÓMEZ-JARA DÍEZ, "Fundamentos de la responsabilidad penal de las personas jurídicas", Tratado de responsabilidad penal de las personas jurídicas, Navarra. 2012.

GÓMEZ-JARA DÍEZ, C. La culpabilidad penal de la empresa, Madrid, 2010.

GÓMEZ-JARA DÍEZ, C. La culpabilidad penal de la empresa, Madrid, 2005.

GÓMEZ-JARA, C. 'Fortalezas, debilidades y perspectivas de la responsabilidad penal de las personas jurídicas', La responsabilidad penal de las personas jurídicas, ONTIVEROS ALONSO, M. ed., Valencia, 2014.

GONZÁLEZ NAVARRO, F. Comentarios a la Ley de Régimen Jurídico de las Administraciones Públivas y Procedimiento Administrativo Común, Madrid, 2007.

GRACIA MARTÍN, L. "La cuestión de la responsabilidad penal de las personas jurídicas”, Act. Penal, n³9, 1993.

GUARDIOLA LAGO, M Responsabilidad penal de las personas juridicas, Valencia, 2004.

HIRSCH, H.J. "La cuestión de la responsabilidad penal de las asociaciones de personas", Anuario de derecho penal y ciencias penales, n²3, 1993. 
IZQUIERDO CARRASCO, M. "Un caso de aplicación insuficiente del principio de culpabilidad propio del Derecho administrativo sancionador: el caso de las denominadas 'falsas alarmas", Justicia Administrativa, n’37, 2007.

JAKOBS, G. Derecho penal. Parte general, Madrid, 1995.

JESCHECK, H.-H.; WEIGEND, T. Tratado de Derecho Penal, Granada, 2002.

KREMNITZER, M.; GHANAYIM, K. "Die Strafbarkeit von Unternehmen”, Zeitschrift für die gesamte Strafrechtswissenschaft, n¹13, 2001.

LASCURAÍN SÁNCHEZ, J.A. "Compliance, debido control y unos refrescos", El derecho penal económico en la era compliance, ARROYO ZAPATERO, L et al ed., Valencia, 2013.

LAUFER, W. Corporate bodies and guilty minds, Chicago, 2006.

LEMKE, M; MOSBACHER, A. Ordnungswidrigkeitengesetr, Heidelberg, 2005.

MATA BARRANCO, N.J. de la et al., "La atribución de responsabilidad penal a las personas jurídicas y su exención: instrumentos de prevención en el seno corporativo", La Ley Penal, nº 87, 2011.

MEDINA OSÓRIO, F. Direito administrativo sancionador, São Paulo, 2015.

MIR PUIG, S. Derecho penal. Parte general, Barcelona, 2015.

MITSCH, W. Recht der Ordnungswidrigkeiten, Heidelberg, 2005.

MUÑOZ DE MORALES ROMERO, M. "Programas de cumplimiento 'efectivos' en la experiencia comparada", El derecho penal económico en la era compliance, ARROYO ZAPATER et al ed., Valencia, 2013.

NIETO MARTÍN, A. Fraudes comunitarios (Derecho penal económico europeo), Barcelona, 1996. 
NIETO MARTÍN, A. La responsabilidad penal de las personas jurídicas: un modelo legislativo, Madrid, 2008.

NIETO, A. Derecho administrativo sancionador, Madrid, 2012.

PALIERO, C; TRAVI, A. Le sanzioni amministrativa, Milano, 1988,

PALMA HERRERA, J. Procedimientos operativos estandarizados y responsabilidad penal de la persona jurídica, Madrid, 2014.

PEMÁN GAVÍN. El sistema sancionador español. Hacia una teoría general de las infracciones y sanciones administrativas, Barcelona, 2000.

PÉREZ FERNÁNDEZ, P. "La importancia de los programas de cumplimiento (compliance programmes) en las políticas sancionadoras de las autoridades de competencia”, Revista de Derecho Mercantil, n²92, 2014.

PÉREZ MACHO, A.I., La responsabilidad penal de las personas jurídicas en el Código Penal español, Granada, 2018.

PINTO, A. et al, Corporate criminal liability, London, 2008.

RANDO CASERMEIRO, P., La distinción entre el Derecho penal y el Derecho administrativo sancionador. Un análisis de política jurídica, Valencia, 2010.

RASCHAUER, N.; WESSELY, N., Verwaltungsstrafrecht. Allgemeiner Teil, Wien- Graz, 2005.

REBMANN, K. et al, Gesetz über Ordnungswidrigkeiten, Stuttgart, 2016

REBOLLO PUIG, M. Potestad sancionadora, alimentación y salud pública, Madrid, 1989.

RODRÍGUEZ RAMOS, L. "Societas delinquere potest! Nuevos aspectos dogmáticos y procesales de la cuestión”, La Ley, 1996.

ROGALL, K. Karlsruber Kommentar zum Gesetz über Ordnungswidrigkeiten, München, 2014. 
ROSENKÖTTER, G. Das Recht der Ordnungswidrigkeiten, Stuttgart, 2002.

ROXIN, C. Derecho penal Parte general, Madrid, 1997.

SCHÜNEMANN, B. Unternehmenskriminalität und Strafrecht, München, 2000.

SUAY RINCÓN, J. "Principio de legalidad en materia sancionadora y su eficacia en el ámbito del crédito", Revista de Derecho Bancario y Bursátil, n³4, 1989.

THIESS, U. Ordnungswidrigkeitenrecht, Berlin, 2002.

TIEDEMANN, K. 'Die "Bebüssung" von Unternehmen nach dem 2 Gesetz zur Bekämpfung der Wirtschaftskrimimalität', NJW, n41, 1988.

TOledo, O. de; HUERTA TOCILDO, S. Derecho Penal. Parte general, Madrid, 1985.

TORÍO LÓPEZ, A. "El concepto individual de culpabilidad", Anuario de derecho penal y ciencias penales, 1985.

TREDER, L. Ordnungswidrigkeitenrecht, Heidelberg, 1996.

WELLS, C. Corporations and criminal responsibility, Oxford, 2001.

ZORNOZA PÉREZ, J.J. El sistema de infracciones y sanciones tributarias (Los principios constitucionales del derecho sancionador), Madrid, 1992.

ZUGALDÍA ESPINAR, J. "Capacidad de acción y capacidad de culpabilidad de las personas jurídicas”, CPC, 1994

ZUGALDÍA ESPINAR, J. "La responsabilidad penal de las personas jurídicas en el Derecho penal español”, El Nuevo Derecho penal español Estudios Penales en Memoria del Profesor José Manuel V alle Muñiz, Valencia, 2001.

ZÚÑIGA RODRÍGUEZ, L. Bases para un modelo de imputación de responsabilidad penal a las personas jurídicas, Granada, 2010. 